\title{
PreVAlence, DeTECTION, SyMPTOMS OF INTOXICATION AND TREATMENT OF NEW FENTANYL ANALOGUE OVERDOSE WITH CYKLOPROPYLFENTANYL (MAF) AS AN EXAMPLE
}

\section{ROZPOWSZECHNIENIE, IDENTYFIKACJA, OBJAWY INTOKSYKACJI I LECZENIE ZATRUĆ NOWYMI ANALOGAMI FENTANYLU NA PRZYKŁADZIE CYKLOPROPYLOFENTANYLU (MAF)}

Sylwia Fudalej

Chair and Department of Psychiatry, Warsaw Medical University, Poland

Katedra i Klinika Psychiatryczna, Warszawski Uniwersytet Medyczny, Polska

\section{Abstract}

The mortality rate attributable to new fentanyl analogue intoxication is a serious issue in various regions, especially in the U.S. In Poland, there have been poisonings reported since 2014 as regards these substances. The number of fatal fentanyl derivative overdoses is certainly underestimated as the analytical techniques required for detection are highly specialised. The toxicity of fentanyl analogues is particularly high due to their potency being many times greater than that of morphine; e.g. carfentanil is 10,000

\section{Streszczenie}

Śmiertelność związana $\mathrm{z}$ intoksykacją nowymi analogami fentanylu jest dużym problemem w różnych rejonach świata, przede wszystkim w Stanach Zjednoczonych. W Polsce już od 2014 r. notowano zatrucia tymi substancjami. Liczba zgonów po przedawkowaniu nowych analogów fentanylu jest z pewnością niedoszacowana ze względu na wysokospecjalistyczne techniki analityczne potrzebne do identyfikacji. Ich szczególnie wysoka toksyczność wiąże się z siłą działania wielokrotnie wyższą od morfiny, np. karfentanyl jest 10000 razy

Correspondence to/Adres do korespondencji: Katedra i Klinika Psychiatryczna, Warszawski Uniwersytet Medyczny, ul. Nowowiejska 27, 00-665 Warszawa, Polska, phone: +48 2282512 36, fax: +48 22825 1315, e-mail: sylwia.fudalej@wum.edu.pl

Authors' contribution/Wkład pracy autorów:

No ghostwriting declared./Nie występuje zjawisko ghostwriting.

Submitted/Otrzymano: 16.04.2021 • Accepted/Przyjęto do druku: 28.09.2021

(C) 2021 Institute of Psychiatry and Neurology. Production and hosting by Termedia sp. z o.o.

This is an open access article under the CC BY-NC-ND license (http://creativecommons.org/licenses/by-nc-nd/4.0/) 
times more active than morphine. This is due to its better lipid solubility and easier penetration through the blood-brain barrier. Every year, new fentanyl derivatives are synthesized with one being cyclopropylfentanyl, known in Poland as MAF. The most common symptoms of fentanyl derivative overdose are similar to those of other opioids. However, less specific symptoms such as hallucinations, delusions, depression, anxiety, agitation, confusion and loss of consciousness can occur. The most life-threatening overdose symptom is respiratory depression, which is more severe and occurs faster than with heroin overdose. Usually, a higher dose of naloxone is needed. The recommended treatment is the administration of repeated and rapidly increasing doses of naloxone. High fentanyl overdose death prevention efficacy has been noted for "Take-home naloxone" programmes.

The present paper reviews the current data on the prevalence, overdose and detection of cyclopropylfentanyl. Clinical cases of cyclopropylfentanyl intoxication have been discussed based on the available literature. The recommended management of overdose and dependence on fentanyl derivatives has been discussed.

Keywords: New fentanyl analogues, Intoxication, Mortality. bardziej aktywny niż morfina. Wynika to z lepszej rozpuszczalności w lipidach i łatwiejszego przenikania przez barierę krew-mózg. Rokrocznie syntetyzowane są nowe pochodne fentanylu. Jedną $\mathrm{z}$ nich jest cyklopropylofentanyl, znany $\mathrm{w}$ Polsce pod nazwą MAF. Najczęstsze objawy przedawkowania pochodnych fentanylu są podobne do objawów po zażyciu innych opioidów. Mogą jednak wystąpić mniej charakterystyczne symptomy, np. halucynacje, urojenia, obniżenie nastroju, lęk, pobudzenie, dezorientacja i zaburzenia świadomości. Najpoważniejsze powikłanie to depresja oddechowa - bardziej nasilona i pojawiająca się szybciej niż po przedawkowaniu heroiny. Do jej odwrócenia zwykle potrzebna jest wyższa dawka naloksonu. Zalecane leczenie polega na podawaniu powtarzanych i szybko zwiększających się dawek naloksonu. Wysoką skuteczność w zapobieganiu zgonom związanym $\mathrm{z}$ przedawkowaniem fentanylu opisywano $\mathrm{w}$ przypadku stosowania programów prewencyjnych typu „Take-home naloxone”.

$\mathrm{W}$ pracy przedstawiono aktualne dane dotyczące rozpowszechnienia, identyfikacji i działania cyklopropylofentanylu. Opisano przypadki kliniczne intoksykacji zebrane na podstawie dostępnego piśmiennictwa. Omówiono zalecane postępowanie w sytuacji przedawkowania nowych pochodnych fentanylu i uzależnienia od tych substancji.

Słowa kluczowe: nowe pochodne fentanylu, intoksykacja, śmiertelność.

\section{- INTRODUCTION}

Synthetic opioids have recently become a major social problem. Acute intoxication and fatalities caused by these substances have been identified in many countries including Poland. The largest increase in the number of cases has been reported in the United States [1-3]. Although the beginning of the "opioid epidemic" observed in the US has been linked with the widespread availability of pharmaceutical opioids. It gradually transformed into an increase in death rates resulting from overdoses of illicit non-methadone synthetic opioids, especially fentanyl and its analogues.

The number of newly synthesized substances is growing rapidly and even users find it difficult to predict their adverse effects. The potency of

\section{- WPROWADZENIE}

Syntetyczne opioidy stały się w ostatnich latach dużym problemem społecznym. Zatrucia i zgony po zażyciu tych substancji notowane są $\mathrm{w}$ wielu krajach, w tym w Polsce. Największy wzrost ich liczby ma miejsce w Stanach Zjednoczonych [1-3]. Początek obserwowanej tam „epidemii opioidowej" wiązany jest $\mathrm{z}$ szeroką dostępnością opioidów przepisywanych na receptę. Stopniowo ten trend przekształcił się we wzrost liczby zgonów w wyniku przedawkowania nielegalnych, innych niż metadon, syntetycznych opioidów, a w szczególności fentanylu i jego pochodnych.

Lawinowo rośnie liczba nowo zsyntetyzowanych substancji, których działanie jest trudne do przewidzenia nawet dla ich użytkowników. Siła działania nowych pochodnych fentanylu może 
the new fentanyl derivatives may be very high; e.g. the analgesic potency of carfentanil has been reported to be up to 10,000 times that of morphine. It is also relatively easily obtainable as it is used in veterinary medicine as an anaesthetic for large animals [4]. Since 2017, a new analogue of fentanyl, cyclopropylfentanyl known in Poland as MAF has been available. The use of MAF is associated with a high risk of death $[1,3]$.

The present study aims:

1. Analyse current global data on fatal and nonfatal opioid overdoses in Poland and all over the world, with particular emphasis on new fentanyl analogues.

2. Present a literature review on the selected new fentanyl analogue cyclopropylfentanyl, including available information on its prevalence, suggested detection and action, possible adverse effects of use, recommended treatment and published case reports.

3. Discuss recommended strategies for dependence treatment of new fentanyl synthetic derivatives and procedures in case of overdose.

\section{- FENTANYL ANALOGUE INTOXICATION - THE CURRENT SITUATION IN POLAND AND WORLDWIDE}

According to WHO data, approximately 27 million people worldwide are opioid-dependent. Although the vast majority of them use heroin, the percentage of those who use prescribed opioids is systematically growing [5]. Nearly half of all drug-related deaths occur due to opioid overdose [5]. Drug overdose mortality is particularly high in the United States, with an increase in the number of deaths from 6.1 to 21.7 per 100,000 (a 3.6-fold increase) between 1999 and 2017 with a simultaneous increase in non-fatal overdoses. The greatest increase in mortality rates between 1999 and 2017 was recorded for overdoses of synthetic opioids other than methadone, especially fentanyl and its derivatives, which is an increase from 0.3 to 9.0 per 100,000 (a 30-fold increase). At the same time, the fatal overdose rates associated with other opioids use increased much slower and were, in the case of heroin, an increase from 0.7 to $4.0 / 100,000$, semi-synthetic opioids, i.e. oxycodone and hydrocodone from być bardzo duża, np. karfentanyl jest 10000 razy bardziej aktywny od morfiny i stosunkowo łatwo dostępny, ponieważ używa się go w weterynarii jako anestetyk dla dużych zwierząt [4]. W 2017 r. pojawił się nowy analog fentanylu - cyklopropylofentanyl, znany w Polsce pod nazwą MAF, którego używanie wiąże się z wysokim ryzykiem zgonu $[1,3]$.

Cele pracy:

1) analiza aktualnych danych dotyczących zatruć na skutek przedawkowania opioidów w Polsce i na świecie, ze szczególnym uwzględnieniem nowych pochodnych fentanylu,

2) przedstawienie przeglądu piśmiennictwa dotyczącego wybranego nowego analogu fentanylu - cyklopropylofentanylu, w tym dostępnych informacji odnoszących się do jego rozpowszechnienia, metod identyfikacji i działania, możliwych skutków niepożądanych, rekomendowanego leczenia oraz do opisu przypadków klinicznych,

3) omówienie zalecanego leczenia uzależnienia od nowych syntetycznych pochodnych fentanylu i postępowania w przypadku ich przedawkowania.

\section{ZATRUCIA POCHODNYMI} FENTANYLU - AKTUALNA SYTUACJA W POLSCE I NA ŚWIECIE

Według danych WHO około 27 milionów ludzi na świecie jest uzależnionych od opioidów. Pomimo że nadal zdecydowana większość z nich zażywa heroinę, systematycznie zwiększa się odsetek osób używających opioidów przepisywanych na receptę [5]. Blisko połowa wszystkich zgonów związanych z narkotykami następuje na skutek przedawkowania opioidów [5]. Śmiertelność przy przedawkowaniu narkotyków jest szczególnie wysoka w Stanach Zjednoczonych, gdzie w latach 1999-2017 odnotowano wzrost liczby zgonów z 6,1 do 21,7 na 100000 ludności (3,6-krotny wzrost), przy jednoczesnym wzroście zatruć nieprowadzących do śmierci. Największy wzrost śmiertelności w latach 1999-2017 odnotowano w odniesieniu do przedawkowania syntetycznych opioidów innych niż metadon, a zwłaszcza fentanylu i jego pochodnych - 30-krotny wzrost, tj. z 0,3 do 9,0 na 100000 ludności. W tym samym okresie śmiertelność związana z zatruciami innymi opioidami rosła znacznie wolniej - w przypadku heroiny był to wzrost z 0,7 do 4,0/100 000, półsyntetycznych 
1.0 to $4.4 / 100,000$ and methadone from 0.3 to $1.0 / 100,000$ [6].

Fentanyl is 50 to 100 times more potent than morphine [7]. Fentanyl analogues have even stronger effects, among others sufentanil, alfentanil, remifentanil, acetylfentanil, butyryl fentanyl, betahydroxythiofentanyl, and carfentanil [4]. It is worth recalling that in 2002, Russian Special Forces deployed a chemical aerosol comprised of a mixture of carfentanil and remifentanil against Chechen terrorists in the Dubrovka theatre in Moscow which caused the deaths of 125 hostages [8].

Fentanyl is a potent agonist of $\mu$-opioid receptors, which play an important role in the development of physical dependence. Their activation can cause euphoria, sedation, analgesia but also the most serious side effect that is respiratory depression. Fentanyl has less effect on the other opioid receptors. In addition, it reduces the concentration of endorphins and increases serotonergic activity, among others through $5-\mathrm{HT}_{1 \mathrm{a}}$ receptors that modulate the central regulation of respiratory functions. Unlike hydrophilic morphine, fentanyl is highly lipophilic thus quickly crosses the bloodbrain barrier and acting primarily on the brain's pain control system. After intravenous administration, its action is immediate [7]. The pharmacokinetics of fentanyl and its derivatives and the lack of knowledge about the potency of these opioids among recreational users increases the risk of fatal overdose.

According to the CDC (Centers for Disease Control and Prevention) [9] the majority of illicitly manufactured fentanyl and its analogues are synthesized in clandestine laboratories in China and Mexico. The wholesale cost of illegal fentan$\mathrm{yl}$ is twenty times lower than the cost of heroin, which is why it is often cut to increase heroin potency and reduce production costs [10].

Fentanyl intoxication is referred to as a "plague" in the United States, but it is also a serious problem in other regions like Europe (including Sweden, Finland, Estonia, Austria, Switzerland, Belgium), Asia (Japan), North America (Canada) and South America (Brazil). According to data published by the European Monitoring Centre for Drugs and Drug Addiction (EMCDDA), 5,141 drug overdose deaths (5,769 including Norway and Turkey) were recorded in the European Union in 2019, of opioidów, tj. oksykodonu i hydrokodonu - wzrost z 1,0 do 4,4/100 000, metadonu - wzrost z 0,3 do 1,0/100 000 ludności [6].

Siła działania fentanylu jest 50-100 razy większa w porównaniu z morfiną [7]. Jeszcze silniejsze działanie mają analogi fentanylu, m.in. sufentanyl, alfentanyl, remifentanyl, acetylofentanyl, butyrofentanyl, betahydroksytiofentanyl oraz karfentanyl [4]. Warto przypomnieć, że w 2002 r. w moskiewskim teatrze na Dubrowce rosyjskie oddziały specjalne użyły przeciwko czeczeńskim terrorystom gazu zawierającego mieszaninę karfentanylu i remifentanylu, który spowodował śmierć 125 zakładników [8].

Fentanyl jest silnym agonistą receptorów opioidowych typu $\mu$, które odgrywają istotną rolę $\mathrm{w}$ rozwijaniu się fizycznego uzależnienia. Ich aktywacja może powodować euforię, sedację, analgezję, ale także najpoważniejszy skutek uboczny, czyli depresję oddechową. Fentanyl słabiej działa na pozostałe receptory opioidowe. Dodatkowo powoduje zmniejszenie stężenia endorfin i zwiększa aktywność serotoninergiczną, m.in. przez receptory typu $5-\mathrm{HT}_{1 \mathrm{a}}$, które modulują ośrodkową regulację funkcji oddechowych. W przeciwieństwie do hydrofilnej morfiny, fentanyl jest wysoce lipofilny, co sprawia, że szybko pokonuje barierę krew-mózg i działa przede wszystkim na układ kontroli bólu w mózgu. Po podaniu dożylnym jego działanie jest natychmiastowe [7]. Taka farmakokinetyka fentanylu i jego pochodnych oraz brak wiedzy o sile działania tych opioidów wśród osób stosujących je w celach rekreacyjnych zwiększa ryzyko przedawkowania ze skutkiem śmiertelnym.

Według danych publikowanych przez CDC (Centers for Disease Control and Prevention) [9] nielegalny fentanyl i jego pochodne są najczęściej syntetyzowane w laboratoriach w Chinach i Meksyku. Szacuje się, że hurtowy koszt fentanylu jest 20 razy niższy w stosunku do kosztu heroiny, dlatego często dodaje się go do heroiny, aby wzmocnić jej działanie i obniżyć koszty produkcji [10].

Zatrucia fentanylem są określane mianem „plagi” w Stanach Zjednoczonych, stanowią jednak poważny problem także w innych regionach, m.in. w Europie (Szwecja, Finlandia, Estonia, Austria, Szwajcaria, Belgia), Azji (Japonia), Ameryce Północnej (Kanada) czy Ameryce Południowej (Brazylia). Zgodnie z danymi publikowanymi przez Europejskie Centrum Monitorowania Narkotyków i Narkomanii (EMCDDA) w 2019 r. w Unii Europejskiej odnotowano 5141 zgonów (5769 przy uwzględnieniu Norwegii i Turcji) związanych z przedawkowaniem narkotyków, z czego opioidy stanowiły 76\% [11]. Choć liczba ta jest 
which opioids accounted for 76\% [11]. Although this number is slightly lower compared to the revised 2018 data (5,920 deaths including Norway and Turkey, and the UK excluded), it should be noted that in most southern and eastern European countries there were more fatal poisonings in 2019 than in 2018. Most victims were male (75\%) with an average of 42 years of age.

According to the EMCDDA report [11], 199 drug overdose deaths were recorded in 2018 in Poland. Samples seized by the Polish police and customs services included cannabinoids, amphetamines and less frequently cocaine, 3,4-Methylenedioxymethamphetamine (MDMA), 3,4-Methylenedioxyamphetamine (MDA) and 3,4-Methylenedioxy-N-ethylamphetamine (MDEA) [11].

Since 2009, 67 new synthetic opioids have been identified in Europe, 38 of which were fentanyl derivatives. The police are systematically seizing more of these substances. Seizures of fentanyl analogues in 2019 amounted to $15 \mathrm{~kg}$, which is a significant increase on 2018, when $6 \mathrm{~kg}$ were confiscated. Precursors of fentanyl are also intercepted, including more than $33 \mathrm{~kg}$ of N-phenyl-4-piperidone (NPP), which were seized in two separate cases in Estonia in 2019 [11].

Overdoses from fentanyl and its analogues have also been reported in Poland since 2014 $[12,13]$. In December 2018, the Chief Sanitary Inspectorate published data on an increase in the number of poisonings and deaths due to the use of synthetic opioids contained in products named: FU-F, Gumiś, Talizman GT, Talisman Green, Triangle, China Breath and Devil Liquid [14]. In 2018, 4,260 medical interventions related to new psychoactive substances (NPS) overdose/suspected overdose were recorded in Poland, they mainly concerned men (85.4\%) and usually individuals aged 19-24. Finally, 162 deaths related to NPS (including among others 4-fluoro-isobutylfentanyl) were confirmed in 2018 [1]. In 2019, a decrease in this kind of intervention in Poland was recorded (2,178 cases from January to November 2019) [15].

It should be emphasised that the above-described data on NPS poisoning in Poland is certainly underestimated due to the poor availability of sensitive methods for identifying these sub- nieznacznie niższa w porównaniu ze skorygowanymi danymi z 2018 r. (5920 zgonów, z uwzględnieniem Norwegii i Turcji oraz wyłączeniem Wielkiej Brytanii), to należy zaznaczyć, że w 2019 r. w większości krajów południowej i wschodniej części Europy odnotowano więcej zatruć śmiertelnych niż w $2018 \mathrm{r}$. Trzy czwarte ofiar stanowili mężczyźni. Średni wiek ofiar wynosił 42 lata.

W Polsce, zgodnie z raportem EMCDDA [11], w 2018 r. zarejestrowano 199 zgonów związanych z przedawkowaniem narkotyków. W przejętych przez polską policję i służby celne próbkach stwierdzano najczęściej kannabinole, amfetaminę, rzadziej kokainę, 3,4-metylenodioksymetamfetaminę (MDMA), 3,4-metylenodioksyamfetaminę (MDA) i 3,4-metylenodioksy-N-etyloamfetaminę (MDEA) [11].

Od 2009 r. w Europie zidentyfikowano 67 nowych syntetycznych opioidów, z czego 38 stanowiły pochodne fentanylu. Systematycznie dochodzi do przejmowania tych środków odurzających przez policję. Konfiskaty pochodnych fentanylu w 2019 r. wyniosły $15 \mathrm{~kg}$, co stanowi znaczny wzrost w porównaniu z 2018 r., kiedy zarekwirowano $6 \mathrm{~kg}$. Przejmowane są również prekursory fentanylu, m.in. w 2019 r. w dwóch oddzielnych przypadkach w Estonii skonfiskowano ponad $33 \mathrm{~kg}$ $\mathrm{N}$-fenylo-4-piperydonu (NPP) [11].

Od 2014 r. zatrucia fentanylem i jego pochodnymi są stwierdzane również w Polsce $[12,13]$. Główny Inspektorat Sanitarny w grudniu $2018 \mathrm{r}$. informował o wzroście liczby przypadków zatruć i zgonów $\mathrm{z}$ powodu użycia opioidów zawartych $\mathrm{w}$ nowych narkotykach, m.in. w produktach o nazwach: FU-F, Gumiś, Talizman GT, Talizman Zielony, Trójkąt, China Breath, Devil Liquid [14]. W 2018 r. w Polsce odnotowano 4260 interwencji medycznych związanych z zatruciem lub podejrzeniem zatrucia nowymi substancjami psychoaktywnymi (NSP). Dotyczyły one w przeważającej mierze mężczyzn (85,4\%), najczęściej osób w przedziale wiekowym 19-24 lat. Ostatecznie w 2018 r. potwierdzono 162 zgony związane z NSP. Jako ich przyczynę raportowano m.in. 4-fluoro-izobutylofentanyl [1]. W 2019 r. odnotowano w Polsce spadek interwencji z powodu podejrzewanych zatruć NSP (2178 przypadków w okresie od stycznia do listopada 2019 r.) [15].

Należy zdecydowanie podkreślić, że wyżej opisane dane dotyczące zatruć NSP w Polsce są $\mathrm{z}$ całą pewnością niedoszacowane ze względu na słabą dostępność czułych metod identyfikujących te substancje. Mogło to wpływać na niskie wskaźniki zatruć raportowanych przez Krajowe Biuro 
stances. This may have influenced the low numbers reported by the National Bureau for Drug Prevention [15], it seems highly probable that many cases could have been classified as poisoning with classic drugs like heroin easily detected using widely available methods with an absence of identification of coexisting NPS poisoning.

Currently, in Poland, the Regulation of the Minister of Health of August 17, 2018, on the list of psychotropic substances, intoxicants and new psychoactive substances is in force (Journal of Laws of 2018, item 1591). It also contains fentanyl and its derivatives (group IV-NPS) $[1,15]$.

\section{- CYCLOPROPYLFENTANYL, ONE OF THE NEW FENTANYL}

\section{ANALOGUES, KNOWN ALSO BY ITS STREET NAME AS MAF}

There are dozens of novel fentanyl synthetic derivatives, one of them is N-phenyl-N-[1-(2phenylethyl) piperidin-4-yl]cyclopropanecarboxamide, commonly known as cyclopropylfentanyl. This new fentanyl analogue was first seized in Europe, in Latvia, Riga in August 2017. Like fentanyl, this substance belongs to the anilidopiperidine class of synthetic opioids. The available opioid panels are not sensitive enough to detect cyclopropylfentanyl. The identification of cyclopropylfentanyl and its metabolites requires highly specialised techniques. The following analytical methods are recommended: high-performance liquid chromatography with a diode-array detector (HPLC-DAD), liquid chromatography tandem mass spectrometry (LC-MS/MS), qualitative tandem liquid chromatography and quadrupole time of flight mass spectrometry (LC-QTOF-MS/ MS) $[16,17]$.

According to the EMCDDA report [3] based on data from 20 European countries, cyclopropylfentanyl is traded under various "street" names: e.g. cyclopropyl or synthetic heroin in Belgium, 4-me-MAF in Sweden and MAF in Poland. In the majority of cases, it is found in powder form, less often as a liquid or pills. It is usually sold through a website as a "legal substitute" for opioids or prescription opioid drugs. It is advertised as a painkiller or drug for reducing the symptoms of opioid withdrawal syndrome. A total of 78 deaths related to the use of cyclopropylfentanyl were re- do spraw Przeciwdziałania Narkomanii [15], wydaje się bowiem wysoce prawdopodobne, że wiele przypadków mogło być klasyfikowanych jako zatrucie łatwo wykrywalnymi narkotykami (np. heroiną), przy braku identyfikacji współistniejącego zatrucia NSP.

Obecnie w Polsce obowiązuje rozporządzenie Ministra Zdrowia z dnia 17 sierpnia 2018 r. w sprawie wykazu substancji psychotropowych, środków odurzających oraz nowych substancji psychoaktywnych (Dz. U. z 2018 poz. 1591). Jest $\mathrm{w}$ nim również umieszczony fentanyl i jego pochodne (grupa IV - NPS) [1, 15].

\section{- CYKLOPROPYLOFENTANYL, ZNANY POD NAZWA ULICZNĄ JAKO MAF - JEDNA Z NOWYCH POCHODNYCH FENTANYLU}

Istnieją dziesiątki nowych syntetycznych pochodnych fentanylu. Jedną $\mathrm{z}$ nich jest $\mathrm{N}$-fenylo-N-[1-(2-fenyloetylo)piperydyn-4-ylo]cyklopropanokarboksyamid, potocznie znany jako cyklopropylofentanyl. Ten nowy analog fentanylu był po raz pierwszy zarekwirowany i zidentyfikowany w Europie na Łotwie, w Rydze, w sierpniu 2017 r. W klasyfikacji syntetycznych opioidów substancja ta, podobnie jak fentanyl, należy do klasy anilidopiperydyn. Nie jest wykrywana w dostępnych panelach stosowanych do detekcji substancji należących do opioidów. Wykrycie cyklopropylofentanylu i jego metabolitów wymaga użycia wysokospecjalistycznych technik. Stosuje się takie metody analityczne, jak: wysokosprawna chromatografia cieczowa sprzężona $\mathrm{z}$ detekcją na matrycy fotodiodowej (HPLC-DAD), chromatografia cieczowa sprzężona $\mathrm{z}$ tandemową spektrometrią mas (LC-MS/MS), chromatografia cieczowa sprzężona ze spektrometrią mas, kwadrupolem i analizatorem czasu przelotu (LC-QTOF-MS/MS) $[16,17]$.

Jak wynika z raportu EMCDDA [3], opracowanego na podstawie danych z 20 państw europejskich, cyklopropylofentanyl jest sprzedawany pod różnymi nazwami „ulicznymi”, np. cyclopropyl lub synthetic heroin w Belgii, 4-me-MAF w Szwecji, MAF w Polsce. Występuje najczęściej w postaci proszku, rzadziej płynu lub tabletek. Jest zwykle sprzedawany przez stronę internetową jako „legalny substytut” opioidów lub leków opioidowych dostępnych na receptęi i reklamowany jako lek przeciwbólowy lub łagodzący objawy opioidowego zespołu odstawiennego. W okresie 
ported to EMCDDA from June to December 2017. The cyclopropylfentanyl poisoning was confirmed in post mortem samples [3]. Sweden has reported the highest number of fatal overdoses. Over $90 \%$ of the victims were middle-aged men. Usually, deaths occurred at home. In 2017, 100 deaths cyclopropylfentanyl use related were confirmed in the United States [2].

In line with EMCDDA data, in the second half of 2017, European Police and Customs Services secured consignments containing cyclopropylfentanyl 59 times, most often in Lithuania and Sweden. In Poland, cyclopropylfentanyl was found already in September 2017 when two packets containing $500 \mathrm{~g}$ of this fentanyl analogue were seized. The parcels were posted in China and reached Poland via Belgium [3]. As mentioned before, this data is underestimated due to the impossibility of detecting cyclopropylfentan$\mathrm{yl}$ in routine tests.

Like other opioids, cyclopropylfentanyl activates the $\mu$-opioid receptors causing euphoria, relaxation, sedation, hypothermia and an analgesic effect. It has many acute side effects, but the most severe is respiratory depression caused by the slowing down of the respiratory rate and amplitude together with a reduction in the sensitivity of central chemoreceptors to carbon dioxide partial pressure. Respiratory depression initiated by cyclopropylfentanyl is associated with a high risk of death. The administration of naloxone is the treatment of choice $[18,19]$. The risk of cyclopropylfentanyl use is particularly high due to the frequent lack of experience of users about its dosage and potency. Sometimes, it is taken by individuals who are not opioid-dependent, which is especially dangerous due to the lack of tolerance. The presence of this substance was also found in samples sold as other psychoactive substances.

So far, only a few papers describing cases of cyclopropylfentanyl overdoses have been published. In 2019, Brede et al. [20] described the death of a 27-year-old man with a history of drug abuse, whose body was found at home in Norway. Eighteen tablets labelled "XANAX 2" resembling commercially available alprazolam medicines were found close to the body. Laboratory diagnostics performed with the use of liquid chromatography-mass spectrometers showed 0.5 od czerwca do grudnia 2017 r. przekazano do EMCDDA informację dotyczącą 78 zgonów związanych z użyciem cyklopropylofentanylu, którego obecność potwierdzono w próbkach pobranych post mortem [3]. Najwięcej zatruć śmiertelnych raportowano w Szwecji. Ponad 90\% ofiar stanowili mężczyźni w średnim wieku i do zgonów dochodziło zazwyczaj w warunkach domowych. W 2017 r. w Stanach Zjednoczonych potwierdzono 100 zgonów spowodowanych użyciem cyklopropylofentanylu [2].

Zgodne $\mathrm{z}$ danymi EMCDDA, w Europie w drugiej połowie $2017 \mathrm{r}$. policja i służby celne zabezpieczyły przesyłki zawierające cyklopropylofentanyl 59 razy, najczęściej na Litwie i w Szwecji. W Polsce cyklopropylofentanyl stwierdzono już we wrześniu 2017 r. - zarekwirowano dwie paczki zawierające po $500 \mathrm{~g}$ tej substancji. Przesyłki zostały nadane w Chinach i dotarły do Polski tranzytem przez Belgię [3]. Jak wcześniej wspomniano, przedstawione dane są niedoszacowane ze względu na brak możliwości wykrywania cyklopropylofentanylu $\mathrm{w}$ rutynowych testach.

Cyklopropylofentanyl, podobnie jak inne opioidy działające przez receptory $\mu$, powoduje euforię, odprężenie, sedację, hipotermię, działa przeciwbólowo. Ma szereg poważnych objawów ubocznych, ale przede wszystkim powoduje depresję układu oddechowego przez spowolnienie i spłycenie czynności oddechowej i zmniejszenie wrażliwości neuronów ośrodka oddechowego na ciśnienie cząstkowe $\mathrm{CO}_{2}$. Depresyjne działanie cyklopropylofentanylu na ośrodek oddechowy wiąże się $\mathrm{z}$ wysokim ryzykiem zgonu. Leczeniem $\mathrm{z}$ wyboru jest podanie naloksonu $[18,19]$. Przyjmowanie cyklopropylofentanylu stanowi szczególnie wysokie zagrożenie spowodowane częstym brakiem doświadczenia osób zażywających tę substancję w zakresie dawkowania i siły działania. Zdarza się, że przyjmują ją osoby nieuzależnione od opioidów, co jest szczególnie niebezpieczne ze względu na brak tolerancji. Stwierdzano również obecność tej substancji w próbkach sprzedawanych jako inne narkotyki.

Dotychczas zostało opublikowanych jedynie kilka prac opisujących przypadki zatruć cyklopropylofentanylem. Brede i wsp. [20] w 2019 r. w Norwegii opisali zgon 27-letniego mężczyzny nadużywającego substancji psychoaktywnych, którego zwłoki odnaleziono w domu. Przy ciele znajdowało się 18 tabletek oznaczonych jako „XANAX 2”, przypominających dostępne na rynku preparaty alprazolamu. Wykonana diagnostyka laboratoryjna (spektrometria masy sprzężonej z chroma- 
mg of cyclopropylfentanyl in each pill. Alprazolam was not detected. Various psychoactive substances were found in post mortem blood and urine samples, including cyclopropylfentanyl, the abuse of which was considered the leading cause of death.

A similar fatal intoxication with cyclopropylfentanyl distributed in the form of a white powder was described in Zurich in a 39-year-old man addicted to various substances and treated with oxycodone for chronic pain [21]. Another five deaths attributed to cyclopropylfentanyl overdose were identified in the United States [22] and one in Spain [23]. In Pennsylvania, 42 blood samples from people from various states, including Florida, Illinois, Michigan, and Tennessee, whose deaths were initially classified as being related to cyclopropylfentanyl or methoxyacetylfentanyl had been carefully analysed. The presence of cyclopropylfentanyl was confirmed in 32 cases [24].

Only a few non-fatal intoxications have been reported. Müller et al. [25] analysed the history of three patients in Germany admitted to hospital due to sedation and respiratory depression. Other symptoms of acute opioid poisoning were also observed as a loss of consciousness, bradypnea, hypercapnia, hypotension and miosis. Patients required repeated doses of naloxone. In one case respiratory therapy had to be administered. Analytical tests confirmed intoxication with cyclopropylfentanyl. In two patients, other synthetic opioids like U-47700, methoxyacetylfentanyl, butyrfentanyl, 2-fluoroiso- and 4-fluoroisobutyrfentanyl were detected simultaneously.

In Germany, a 25-year-old man was admitted to the emergency department after intranasal ingestion of the substance he had bought as fentanyl. He developed nausea, profuse sweating and shortness of breath 10 minutes after inhalation. His clinical condition deteriorated rapidly due to respiratory failure; he lost consciousness and required resuscitation. The emergency team delivered oxygen and repeated the naloxone dose. On admission to the hospital, the patient was in a coma, with miosis and hypothermia $\left(34.9^{\circ} \mathrm{C}\right)$. Blood pressure and heart rate were normal (127/70, 65/min). The patient was hospitalised in the intensive care unit and required oxygen therapy. After one day of observation, he tografią cieczową) wykazała zawartość w każdej tabletce $0,5 \mathrm{mg}$ cyklopropylofentanylu. Nie stwierdzono obecności alprazolamu. W pobranych post mortem próbkach krwi i moczu stwierdzono różne substancje, w tym cyklopropylofentanyl, którego nadużycie przyjęto za główną przyczynę zgonu.

Podobne śmiertelne zatrucie cyklopropylofentanylem rozprowadzanym $\mathrm{w}$ postaci białego proszku opisano w Zurychu u 39-letniego mężczyzny uzależnionego od różnych substancji, leczonego oksykodonem $\mathrm{z}$ powodu przewlekłych dolegliwości bólowych [21]. Kolejnych pięć zgonów w następstwie zatrucia omawianą substancją zidentyfikowano w Stanach Zjednoczonych [22] i jeden w Hiszpanii [23]. W Pensylwanii poddano szczegółowej analizie 42 próbki krwi pobrane od osób pochodzących $\mathrm{z}$ różnych stanów, m.in. z Florydy, Illinois, Michigan i Tennessee, których zgon wstępnie zakwalifikowano jako związany $\mathrm{z}$ użyciem cyklopropylofentanylu lub metoksyacetylofentanylu. W 32 przypadkach potwierdzono obecność cyklopropylofentanylu [24].

Opisano jedynie kilka przypadków intoksykacji niezakończonych śmiercią. Müller i wsp. [25] w Niemczech analizowali historię trzech pacjentów przyjętych do szpitala $z$ powodu sedacji i depresji oddechowej. Obserwowano też inne objawy ostrego zatrucia opioidowego: utratę przytomności, spowolniony oddech (bradypnoë), hiperkapnię, obniżenie ciśnienia tętniczego, zwężenie źrenic. Pacjenci wymagali dwukrotnego podania naloksonu. W jednym przypadku stan był tak poważny, że zastosowano respiratoroterapię. W badaniach analitycznych potwierdzono zatrucie cyklopropylofentanylem. U dwóch chorych wykryto jednocześnie inne syntetyczne opioidy: U-47700, metoksyacetylofentanyl, butyrofentanyl, 2-fluoroiso- i 4-fluoroisobutyrofentanyl.

W Niemczech na oddział ratunkowy został przyjęty 25-letni mężczyzna, u którego 10 minut po przyjęciu donosowej substancji, którą kupił jako fentanyl, wystąpiły nudności, zlewne poty i duszność. Stan kliniczny szybko się pogorszył z powodu niewydolności oddechowej, pacjent stracił przytomność, wymagał resuscytacji. Zespół pogotowia ratunkowego podał tlen i podwójną dawkę naloksonu. Przy przyjęciu do szpitala pacjent był w śpiączce, hipotermii $\left(34,9^{\circ} \mathrm{C}\right)$ i miał wąskie źrenice, ciśnienie krwi i tętno były w normie (127/70, 65/min). Pacjenta hospitalizowano na oddziale intensywnej terapii, wymagał tlenoterapii. Po dobie obserwacji został wypisany ze szpi- 
was discharged from hospital. Analysis of a collected urine sample confirmed the presence of cyclopropylfentanyl and its metabolite cyclopropylnorfentanyl. At the same time, the presence of other drugs was detected, the use of which was confirmed by the patient [26].

\section{- TREATMENT OF NEW FENTANYL ANALOGUE DEPENDENCE AND PROCEDURE IN CASE OF OVERDOSE}

The precise data on fentanyl derivative potency activity, pharmacology and adverse effects is still very limited. The effects of fentanyl analogues are similar to other opioids and include analgesia, euphoria, drowsiness, relaxation and skeletal muscle tension reduction [27]. Fentanyl and fentanyl analogues have a lot of adverse effects which can be grouped as:

- somatic side effects incl. constipation, nausea, vomiting, itching, a bitter taste after oral ingestion, sweating, miosis, orthostatic hypotension, urinary urgency or retentions,

- psychiatric side effects i.e. anxiety, disorientation, agitation, dysphoria, depression, loss of consciousness or very rare delusions and hallucinations $[28,29]$.

New fentanyl derivative overdoses are particularly dangerous due to their high lipophilicity, which allows for rapid absorption across the bloodbrain barrier and high affinity and selectivity for the $\mu$-opioid receptor and other opioid receptors [30]. The most serious symptom is respiratory depression associated with risk of death. Fentanyl and its analogues cause more rapid onset of severe life-threatening respiratory depression than other opioids. The onset of respiratory arrest caused by fentanyl/fentanyl analogues was estimated at two minutes, whereas in the case of heroin it is up to 10 minutes [31].

According to WHO recommendations [32], when an opioid overdose is suspected, airway management (checking and clearing the airway, checking respiration, turning patients to side position) should be first applied. Oxygen should be supplied when the respiratory rate is lower than 10 breaths per minute. It is recommended to start with an intramuscular dose of $400 \mu \mathrm{g}$ of naloxone, with further $400 \mu \mathrm{g}$ doses given incrementally ev- tala. Analiza pobranej próbki moczu potwierdziła obecność cyklopropylofentanylu i jego metabolitu - cyklopropylonorfentanylu. Jednocześnie wykryto obecność innych narkotyków, których przyjmowanie pacjent potwierdził [26].

\section{- LECZENIE UZALEŻNIENIA OD NOWYCH POCHODNYCH FENTANYLU ORAZ POSTĘPOWANIE W PRZYPADKU ICH PRZEDAWKOWANIA}

Brakuje dokładnych danych o sile działania, farmakologii i skutkach ubocznych nowych pochodnych fentanylu. Wiadomo natomiast, że działają podobnie do innych opioidów: przeciwbólowo, euforycznie, nasennie, sedatywnie, zmniejszają napięcie mięśni szkieletowych [27]. Fentanyl i analogi fentanylu mają wiele działań niepożądanych, które można podzielić na:

- somatyczne skutki uboczne, m.in. zaparcia, nudności, wymioty, świąd, gorzki smak po przyjęciu doustnym, pocenie się, zwężenie źrenic, ortostatyczne niedociśnienie, nagłe parcie na mocz lub zatrzymanie moczu,

- psychiczne skutki uboczne, tj. lęk, dezorientacja, pobudzenie, dysforia, depresja, zaburzenia świadomości czy bardzo rzadko występujące urojenia i omamy $[28,29]$.

Zatrucia tymi substancjami są szczególnie niebezpieczne ze względu na ich wysoką lipofilność, pozwalającą na szybkie przekroczenie bariery krew-mózg, oraz wysokie powinowactwo i selektywność $\mathrm{w}$ stosunku do receptora $\mu \mathrm{i}$ innych receptorów opioidowych [30]. Najpoważniejszym objawem zatrucia jest depresja oddechowa potencjalnie prowadząca do zgonu. Fentanyl i jego analogi powodują szybsze wystąpienie ciężkiej, zagrażającej życiu depresji oddechowej niż inne opioidy. Początek zatrzymania oddechu spowodowany przez fentanyl/analogi fentanylu występuje zwykle po dwóch minutach, podczas gdy w przypadku heroiny czas ten wynosi nawet 10 minut [31].

Zgodnie z zaleceniami WHO [32] w przypadku podejrzenia przedawkowania opioidów w pierwszej kolejności należy ocenić stan chorego, w tym drożność dróg oddechowych, i ułożyć go w pozycji bocznej bezpiecznej, jeśli ma zachowany oddech. Tlen należy podawać, gdy częstość oddechów jest niższa niż 10 na minutę. Zaleca się rozpocząć od podania naloksonu domięśniowo w dawce $400 \mu \mathrm{g}$. Kolejne dawki po $400 \mu \mathrm{g}$ należy podawać stopnio- 
ery 2-3 minutes until an effect is noted or the ambulance arrives [32].

When fentanyl or its analogues overdose is suspected calling an ambulance and transport to the emergency department should be immediate. In case of poisoning with fentanyl derivatives, fast administration of naloxone is recommended.

For in-hospital fentanyl or fentanyl analogue overdose treatment, the following naloxone dosing regime was recommended by the UK Department of Health [28]:

- an initial dose of $400 \mu \mathrm{g}(0.4 \mathrm{mg})$ intravenously,

- if there is no response, after 60 seconds give a further $800 \mu \mathrm{g}(0.8 \mathrm{mg})$,

- if there is still no response, after another $60 \mathrm{sec}$ onds give another $800 \mu \mathrm{g}(0.8 \mathrm{mg})$,

- if there is still no response, give a further $2 \mathrm{mg}$ dose.

Large doses (up to $4 \mathrm{mg}$ ) may be required in a seriously poisoned patient. At the same time, resuscitation should be performed. The aim of the treatment should be the reversal of respiratory depression, not the full reversal of consciousness. Another important aspect of treatment is difficulty in balancing between the need for an effective opioid antidote (naloxone) and the risks of acute withdrawal symptoms in dependent persons.

In heroin overdose patients, safe discharge from the hospital is possible even after a onehour observation [33]. In case of fentanyl analogues overdose, the necessity of longer observation is recommended because symptoms may recur when the naloxone effect diminishes [30]. Fentanyl, which has a high affinity for the $\mu$-opioid receptor, can dislocate naloxone and reoccupy the receptor and lead to the return of overdose symptoms [34].

The "Take-home naloxone" programme was implemented in the US as a harm-reduction strategy in case of overdose. This programme improves naloxone availability. Naloxone produced as a prepacked kit can be used easily by first responders or nonmedical laypersons (family members, friends). Additional training in recognising the signs of opioid overdose and administration of naloxone for those persons is provided. Nasal administration of naloxone is as effective as the intravenous route and provides similar pharmacokinetic properties [28]. There is a growing body of evidence that this approach is effective with respiratory depression wo co 2-3 minuty, aż do zauważenia efektu lub do przybycia karetki [32].

W przypadku podejrzenia przedawkowania fentanylu lub jego analogów należy natychmiast wezwać pogotowie ratunkowe i przetransportować pacjenta na oddział ratunkowy. Przy zatruciu pochodnymi fentanylu zalecane jest szybkie podanie naloksonu.

W leczeniu szpitalnym po przedawkowaniu fentanylu lub analogów fentanylu Departament Zdrowia Wielkiej Brytanii rekomenduje następujący schemat dawkowania naloksonu [28]:

- dawka początkowa $400 \mu \mathrm{g}(0,4 \mathrm{mg})$ dożylnie,

- jeśli nie ma odpowiedzi po 60 sekundach, podać dalsze $800 \mu \mathrm{g}(0,8 \mathrm{mg})$,

- jeśli po kolejnych 60 sekundach nadal nie ma odpowiedzi, podać kolejne $800 \mu \mathrm{g}(0,8 \mathrm{mg})$,

- jeśli nadal nie ma odpowiedzi, podać kolejną dawkę $2 \mathrm{mg}$.

$\mathrm{U}$ pacjenta $\mathrm{z}$ ciężkim zatruciem mogą być wymagane duże dawki - do $4 \mathrm{mg}$. Jednocześnie należy prowadzić resuscytację. Celem leczenia powinno być odwrócenie depresji oddechowej, a nie całkowite odzyskanie świadomości. Ważnym aspektem leczenia jest odpowiedni dobór dawki naloksonu, która pozwoli na zniesienie depresji oddechowej i nie wywoła ostrych objawów abstynencyjnych u osób uzależnionych.

Pacjenci leczeni $\mathrm{z}$ powodu przedawkowania heroiny mogą być bezpiecznie wypisani ze szpitala nawet po godzinnej obserwacji [33]. W przypadku przedawkowania analogów fentanylu zalecana jest dłuższa obserwacja, ponieważ objawy depresji oddechowej mogą wystąpić ponownie po osłabieniu działania naloksonu [30]. Fentanyl, który ma wysokie powinowactwo do receptora opioidowego $\mu$, może wypierać nalokson i ponownie zajmować receptory opioidowe, a tym samym prowadzić do nawrotu objawów przedawkowania [34].

W niektórych krajach, m.in. Stanach Zjednoczonych, wprowadzono program „Take-home naloxone" jako strategię redukcji szkód w przypadku przedawkowania opioidów. Program ten poprawia dostępność naloksonu. Nalokson, produkowany w postaci aerozolu do nosa $\mathrm{w}$ pojemniku jednodawkowym, może być z łatwością użyty przez ratowników lub inne osoby niezwiązane $\mathrm{z}$ medycyną, np. członków rodziny, przyjaciół. Tym osobom zapewnia się dodatkowe szkolenie w zakresie rozpoznawania objawów przedawkowania opioidów i podawania naloksonu. Donosowe podanie naloksonu jest równie skuteczne jak dożylne i zapewnia podobne właściwości farmakokinetyczne 
symptoms, reversal rate of $79.2 \%$ and survival of suspected opioid overdose victims of $95.9 \%$ [35]. Prepacked nasal naloxone kits are not available in Poland.

Using fentanyl analogues is associated with a high risk of developing dependence, tolerance and withdrawal syndrome similar to those with other opioids. Withdrawal syndrome includes symptoms like sweating, anxiety, diarrhea, bone pain, abdominal cramps, shivers and "goose flesh" [7]. The long-term use of fentanyl can additionally lead to gastrointestinal disturbance, immunological and hormonal dysfunction, hyperalgesia, muscle rigidity and myoclonus [36].

\section{Prevention of fentanyl and fentanyl derivative overdose}

Education seems to play an important role in the prevention of newly synthesized fentanyl derivative overdose. Not only patients but also their families should be aware of these high-potency illicit opioids that are often mixed with other drugs like heroin. Immediate treatment of illicit opioids overdose with naloxone is crucial to reverse respiratory depression. The "Take-home naloxone" programme has been reported to be an effective in overdose fatality prevention. Therefore, registration of the nasal form of naloxone in Poland should be considered. Special medical care should be provided to patients with risk factors for opioid overdose [34] like:

- male gender,

- 35-44 years of age,

- mood disorders in course of dependence,

- a history of suicide attempts,

- a history of overdose,

- discontinuation of maintenance treatment for substance use disorder,

- severe chronic pain,

- high opioid prescription doses,

- a long history of opioid use or misuse,

- opioid use with other substances affecting the central nervous system depressively like alcohol or benzodiazepines,

- intravenous use of opioids,

- mixing other opioids with fentanyl or fentanyl analogues,

- opioid use after a period of abstinence,

- respiratory system diseases.
[28]. Skuteczność programu „Take-home naloxone" ocenia się wysoko: odsetek ustąpienia objawów depresji oddechowej określono na 79,2\%, natomiast przeżywalność ofiar przedawkowania opioidów - na 95,9\% [35]. Donosowe preparaty naloksonu nie są dostępne w Polsce.

Stosowanie analogów fentanylu wiąże się z wysokim ryzykiem rozwoju uzależnienia, tolerancji i wystąpienia zespołu abstynencyjnego, podobnie jak w przypadku innych opioidów. W zespole odstawiennym charakterystyczne są takie objawy, jak: zwiększona potliwość, niepokój, biegunka, bóle kostne, kolka jelitowa, dreszcze i tzw. gęsia skórka [7]. Długotrwałe stosowanie fentanylu może dodatkowo prowadzić do zaburzeń żołądkowo-jelitowych, zaburzeń immunologicznych i hormonalnych, nadwrażliwości na ból, sztywności mięśni i mioklonii [36].

\section{Zapobieganie przedawkowaniu fentanylu i jego pochodnych}

Istotnym elementem zapobiegania zatruciom nowo syntetyzowanymi pochodnymi fentanylu jest edukacja. Nie tylko pacjenci, lecz także ich rodziny powinny być informowane o tych nielegalnych opioidach o dużej sile działania, które są często dodawane do innych narkotyków, np. do heroiny. Natychmiastowe leczenie przedawkowania przez podanie naloksonu ma kluczowe znaczenie dla odwrócenia depresji oddechowej. Program „Take-home naloxone” został zweryfikowany jako skuteczny sposób zapobiegania zgonom związanym z przedawkowaniem opioidów. Należy rozważyć rejestrację formy donosowej naloksonu w Polsce. Szczególnej opieki wymagają pacjenci, u których występują czynniki ryzyka przedawkowania opioidów [34], takie jak:

- płeć męska,

- wiek 35-44 lata,

- zaburzenia nastroju w przebiegu uzależnienia,

- próby samobójcze w wywiadzie,

- przedawkowanie w wywiadzie,

- przerwanie substytucyjnego leczenia zaburzeń używania substancji psychoaktywnych,

- przewlekły silny ból,

- przyjmowanie dużych dawek opioidów na receptę,

- długotrwałe używanie lub nadużywanie opioidów,

- stosowanie opioidów z innymi substancjami działającymi depresyjnie na ośrodkowy układ nerwowy, jak alkohol lub benzodiazepiny,

- dożylne stosowanie opioidów, 


\section{Fentanyl and fentanyl derivative dependence}

Previous research indicated that the most effective opioid dependence prevention programmes were those carried out in groups of children and teenagers. Prevention and education strategies seem to be less successful in adults [37]. It is important to note that vulnerability to opioid dependence is genetically transmitted. The heritability of substance use disorders was estimated at 50\% [38]. This genetic vulnerability overlaps with social and environmental factors that can be adjusted.

No specific treatment approaches have been developed for fentanyl and fentanyl derivative dependence. Methods implemented for other opioids dependence treatment have been used, including maintenance treatment that leads to a reduction in the risk of overdose, infection, and criminal behaviour.

Only animal studies evaluating of the most effective maintenance treatment dosing regimens for methadone, buprenorphine or naltrexone in fentanyl dependence have been conducted. In general, it has been suggested that the effects of stronger agonists of opioid receptors are more difficult to block than lower efficacy agonists. It can be assumed that available maintenance treatment methods can be less effective in the abuse of fentanyl and its derivatives [39]. An important area of dependence treatment is psychotherapy. Previous studies support the effectiveness of psychosocial therapy in combination with pharmacotherapy in treatment of opioid dependence. There are relatively few studies comparing the effectiveness of different psychotherapeutic approaches [40].

\section{- CONCLUSIONS}

Fentanyl derivative overdose mortality rates continue to rise. These substances are also available in Poland. Poisoning with fentanyl analogues, e.g. cyclopropylfentanyl, is associated with a high risk of severe, rapidly developing respiratory depression. Treatment of such intoxication is based on the administration of repeated and rapidly increasing doses of naloxone.

"Take-home naloxone" programmes are reported to be effective opioid lethal overdose prevention tools. It is worth considering the registration of the nasal form of naloxone in Poland and introducing educational campaigns for pa-
- łączenie innych opioidów $\mathrm{z}$ fentanylem lub analogami fentanylu,

- stosowanie opioidów po okresie abstynencji,

- choroby układu oddechowego.

\section{Uzależnienie od fentanylu i jego pochodnych}

Wcześniejsze badania wskazywały, że najskuteczniejsze w zapobieganiu rozwojowi uzależnienia od opioidów są programy profilaktyczne skierowane do dzieci i młodzieży. Strategie interwencyjne i edukacyjne są mniej skuteczne w przypadku dorosłych [37]. Jednocześnie należy zauważyć, że podatność na uzależnienie od opioidów jest warunkowane genetycznie. Odziedziczalność zaburzeń związanych z używaniem substancji psychoaktywnych została oszacowana na 50\% [38]. $\mathrm{Na}$ ujawnienie się tej podatności genetycznej mają wpływ czynniki społeczne i środowiskowe, na które można oddziaływać.

Nie opracowano dotąd żadnych specyficznych metod leczenia uzależnienia od fentanylu i jego pochodnych. Stosowane są metody wdrożone w leczeniu uzależnienia od innych opioidów, w tym leczenie substytucyjne, które prowadzi do zmniejszenia ryzyka przedawkowania, rozwoju infekcji i popełniania przestępstw.

Badania dotyczące oceny najskuteczniejszych schematów leczenia substytucyjnego, czyli dawkowania metadonu, buprenorfiny lub naltreksonu $\mathrm{w}$ przypadku uzależnienia od fentanylu, przeprowadzono dotychczas jedynie na zwierzętach. Wykazano, że działanie silniejszych agonistów receptorów opioidowych jest trudniejsze do zablokowania niż agonistów o niższej skuteczności. Można przypuszczać, że dostępne metody leczenia substytucyjnego mogą być mniej skuteczne w przypadku nadużywania fentanylu i jego pochodnych [39]. Ważnym obszarem leczenia uzależniania jest psychoterapia. Dotychczasowe badania potwierdzają większą skuteczność jednoczesnego stosowania oddziaływań psychospołecznych i farmakoterapii w przebiegu leczenia uzależnienia od opioidów. Istnieje stosunkowo niewiele badań porównujących zróżnicowaną skuteczność różnych szkół psychoterapeutycznych [40].

\section{- WNIOSKI}

Wskaźniki śmiertelności po przedawkowaniu nowych pochodnych fentanylu stale rosną. Substancje te są dostępne również w Polsce. Zatrucia pochodnymi fentanylu, np. cyklopropylofentanylem, 
tients and their relatives regarding new synthetic opioids.

Additionally, it should be mentioned that the available data indicate that the COVID-19 pandemic did not significantly change the availability of psychoactive substances though it could have reduced the availability of medical centre opioid dependence treatment [41]. wiążą się z wysokim ryzykiem nasilonej, szybko rozwijającej się depresji oddechowej. Leczenie takich intoksykacji polega na podawaniu powtarzanych i szybko zwiększających się dawek naloksonu.

Programy prewencyjne typu „Take-home naloxone" są skutecznym narzędziem zapobiegającym przedawkowaniu opioidów ze skutkiem śmiertelnym. Warto rozważyć zarejestrowanie w Polsce donosowej postaci naloksonu oraz wprowadzenie akcji edukacyjnych dla osób uzależnionych i ich bliskich dotyczących nowych syntetycznych opioidów.

Należy dodatkowo zaznaczyć, że dostępne dane wskazują, że pandemia COVID-19 nie zmieniła w istotny sposób dostępności substancji psychoaktywnych, mogła natomiast wpłynąć negatywnie na działanie podmiotów zajmujących się leczeniem uzależnień i ich powikłań [41].

\section{Conflict of interest/Konflikt interesów}

None declared./Nie występuje.

Financial support/Finansowanie

None declared./Nie zadeklarowano.

\section{Ethics/Etyka}

The work described in this article has been carried out in accordance with the Code of Ethics of the World Medical Association (Declaration of Helsinki) on medical research involving human subjects, Uniform Requirements for manuscripts submitted to biomedical journals and the ethical principles defined in the Farmington Consensus of 1997.

Treści przedstawione w pracy są zgodne z zasadami Deklaracji Helsińskiej odnoszącymi się do badań z udziałem ludzi, ujednoliconymi wymaganiami dla czasopism biomedycznych oraz z zasadami etycznymi określonymi w Porozumieniu z Farmington w 1997 roku.

\section{References/Piśmiennictwo}

1. Raport Głównego Inspektora Sanitarnego. Nowe Narkotyki w Polsce 2017-2018. Warszawa: Główny Inspektorat Sanitarny; 2019.

2. Drug Enforcement Administration, Drug and Chemical Evaluation Section, Diversion Control Division. Cyclopropyl Fentanyl - Background Information and Evaluation of 'three Factor Analysis' (factors 4, 5, and 6) for Temporary Scheduling. Springfield, VA; 2017. https://www.deadiversion.usdoj.gov/fed_regs/rules/2017/fr1121.htm (Accessed: 16.04.2021).

3. The European Monitoring Centre for Drugs and Drug Addiction. Report on the Risk Assessment of N-phenyl-N-[1-(2-phenylethyl)piperidin-4-yl]cyclopropanecarboxamide (cyclopropylfentanyl) in the framework of the Council Decision on new psychoactive substances. Risk assesments, Luxembourg: Publications Office of the European Union; 2018. https://www.emcdda.europa.eu/system/files/publications/9607/ Risk\%20assessment\%20cyclopropylfentanyl.pdf (Accessed: 27.11.2021). 
4. Raheemullah A, Andruska N. Fentanyl analogue overdose: Key lessons in management in the synthetic opioid age. J Opioid Manag 2019; 15(5): 428-32.

5. World Health Organization. Management of substance abuse. 2020. https://www.who. int/substance_abuse/information-sheet/en// (Accessed 16.04.2021).

6. Hedegaard H, Minino AM, Warner M. Drug Overdose Deaths in the United States, 19992017. NCHS data brief 2020; (329): 1-8.

7. Suzuki J, El-Haddad S. A review: Fentanyl and non-pharmaceutical fentanyls. Drug Alcohol Depend 2017; 171: 107-16.

8. Riches JR, Read RW, Black RM, Cooper NJ, Timperley CM. Analysis of clothing and urine from Moscow theatre siege casualties reveals carfentanil and remifentanil use. $J$ Anal Toxicol 2012; 36(9): 647-56.

9. Nonpharmaceutical fentanyl-related deaths - multiple states, April 2005-March 2007. MMWR Morb Mortal Wkly Rep 2008; 57(29): 793-6.

10. Frank RG, Pollack HA. Addressing the Fentanyl Threat to Public Health. $N$ Engl J Med 2017; 376(7): 605-7.

11. The European Monitoring Centre for Drugs and Drug Addiction. European Drug Report 2021: Trends and Developments. Luxembourg: Publications Office of the European Union; 2021. https://www.emcdda.europa.eu/publications/edr/trends-developments/2021_en (Accessed: 26.09.2021).

12. Jannetto PJ, Helander A, Garg U, Janis GC, Goldberger B, Ketha H. The Fentanyl Epidemic and Evolution of Fentanyl Analogs in the United States and the European Union. Clin Chem 2019; 65(2): 242-53.

13. Rojkiewicz M, Majchrzak M, Celinski R, Kus P, Sajewicz M. Identification and physicochemical characterization of 4-fluorobutyrfentanyl (1-((4-fluorophenyl)(1-phenethylpiperidin-4-yl)amino)butan-1-one, 4-FBF) in seized materials and post-mortem biological samples. Drug Test Anal 2017; 9(3): 405-14.

14. Główny Inspektorat Sanitarny. Wzrost liczby przypadków zatruć $i$ śmierci z powodu użycia opioidów, zawartych w nowych narkotykach (tzw. ,dopalaczach”). https://www.gov. $\mathrm{pl} /$ web/gis/glowny-inspektor-sanitarny-ostrzega-przed-uzyciem-opioidow (Accessed: 16.04.2021).

15. Malczewski A. Raport o stanie narkomanii w Polsce 2019. Warszawa: Krajowe Biuro do spraw Przeciwdziałania Narkomanii; 2019.

16. Servin FS, Billard V. Remifentanil and other opioids. Handb Exp Pharmacol 2008; 182: 283-311.

17. Maher S, Elliott SP, George S. The analytical challenges of cyclopropylfentanyl and crotonylfentanyl: An approach for toxicological analysis. Drug Test Anal 2018; 10(9): 1483-7.

18. Pasternak GW, Pan YX. Mu opioids and their receptors: evolution of a concept. Pharmacol Rev 2013; 65(4): 1257-317.

19. Pattinson KTS. Opioids and the control of respiration. Brit J Anaesth: BJA 2008; 100(6): 747-58.

20. Brede WR, Krabseth H-M, Michelsen LS, Aarset H, Jamt J-P, Slørdal L. A Wolf in Sheep's Clothing. J Anal Toxicol 2018; 43(2): 7-8.

21. Brockbals L, Staeheli SN, Gentile S, Schlaepfer M, Bissig C, Bolliger SA, et al. Fatal poisoning involving cyclopropylfentanyl - Investigation of time-dependent postmortem redistribution. Forensic Sci Int 2019; 294: 80-5.

22. Fagiola M, Hahn T, Avella J. Five Postmortem Case Reports with Qualitative Analysis of Cyclopropylfentanyl by LC-MS-MS. J Anal Toxicol 2019; 43(4): e1-e6.

23. Matey JM, García-Ruíz C, Montalvo G, Gómez-Soro JC, Gutierrez-Delicado D, Rodríguez-Gallardo J, et al. Ultraviolet-Visible and High-Resolution Mass Spectrometry for the Identification of Cyclopropyl-Fentanyl in the First Fatal Case in Spain. J Anal Toxicol 2020; 44(8): 927-35.

24. Fogarty MF, Papsun DM, Logan BK. Analysis of Fentanyl and 18 Novel Fentanyl Analogs and Metabolites by LC-MS-MS, and report of Fatalities Associated with Methoxyacetylfentanyl and Cyclopropylfentanyl. J Anal Toxicol 2018; 42(9): 592-604. 
25. Müller D, Neurath H, Neukamm MA, Wilde M, Despicht C, Blaschke S, et al. New synthetic opioid cyclopropylfentanyl together with other novel synthetic opioids in respiratory insufficient comatose patients detected by toxicological analysis. Clin Toxicol (Phila) 2019; 57(9): 806-12.

26. Wilde M, Sommer MJ, Auwärter V, Hermanns-Clausen M. Acute severe intoxication with cyclopropylfentanyl, a novel synthetic opioid. Toxicol Lett 2020; 320: 109-12.

27. Miller JM, Stogner JM, Miller BL, Blough S. Exploring synthetic heroin: Accounts of acetyl fentanyl use from a sample of dually diagnosed drug offenders. Drug Alcohol Rev 2018; 37(1): 121-7.

28. Abdulrahim D, Bowden-Jones O; on behalf of the Neptune group. The Misuse of Synthetic Opioids: Harms and Clinical Management of Fentanyl, Fentanyl Analogues and Other Novel Synthetic Opioids. London: NEPTUNE; 2018.

29. Siddiqi S, Verney C, Dargan P, Wood DM. Understanding the availability, prevalence of use, desired effects, acute toxicity and dependence potential of the novel opioid MT-45. Clin Toxicol (Phila) 2015; 53(1): 54-9.

30. Armenian P, Vo KT, Barr-Walker J, Lynch KL. Fentanyl, fentanyl analogs and novel synthetic opioids: A comprehensive review. Neuropharmacology 2018; 134: 121-32.

31. Kim HK, Connors NJ, Mazer-Amirshahi ME. The role of take-home naloxone in the epidemic of opioid overdose involving illicitly manufactured fentanyl and its analogs. Expert Opin Drug Saf 2019; 18(6): 465-75.

32. World Health Organization. Community management of opioid overdose. WHO; 2014. https://apps.who.int/iris/handle/10665/137462 (Accessed 16.04.2021).

33. Willman MW, Liss DB, Schwarz ES, Mullins ME. Do heroin overdose patients require observation after receiving naloxone? Clin Toxicol (Phila) 2017; 55(2): 81-7.

34. Blanco C, Volkow ND. Management of opioid use disorder in the USA: present status and future directions. Lancet 2019; 393(10182): 1760-72.

35. Mahonski SG, Leonard JB, Gatz JD, Seung H, Haas EE, Kim HK. Prepacked naloxone administration for suspected opioid overdose in the era of illicitly manufactured fentanyl: a retrospective study of regional poison center data. Clin Toxicol (Phila) 2020; 58(2): $117-23$.

36. Benyamin R, Trescot AM, Datta S, Buenaventura R, Adlaka R, Sehgal N, et al. Opioid complications and side effects. Pain Physician 2008; 11 (2 Suppl): S105-20.

37. Compton WM, Jones CM, Baldwin GT, Harding FM, Blanco C, Wargo EM. Targeting Youth to Prevent Later Substance Use Disorder: An Underutilized Response to the US Opioid Crisis. Am J Public Health 2019; 109(S3): S185-9.

38. Kendler KS, Myers J, Prescott CA. Specificity of genetic and environmental risk factors for symptoms of cannabis, cocaine, alcohol, caffeine, and nicotine dependence. Arch Gen Psychiatry 2007; 64(11): 1313-20.

39. Comer SD, Cahill CM. Fentanyl: Receptor pharmacology, abuse potential, and implications for treatment. Neurosci Biobehav Rev 2019; 106: 49-57.

40. Dugosh K, Abraham A, Seymour B, McLoyd K, Chalk M, Festinger D. A Systematic Review on the Use of Psychosocial Interventions in Conjunction With Medications for the Treatment of Opioid Addiction. J Addict Med 2016; 10(2): 93-103.

41. The European Monitoring Centre for Drugs and Drug Addiction. European Drug Report 2020: Trends and Developments. Luxembourg: Publications Office of the European Union; 2020. https://www.emcdda.europa.eu/publications/edr/trends-developments/2020_en (Accessed: 16.04.2021). 
